\title{
Novel expression hosts for complex secondary metabolite megasynthetases: Production of myxochromide in the thermopilic isolate Corallococcus macrosporus GT-2
}

\author{
Olena Perlova ${ }^{\dagger 1}$, Klaus Gerth ${ }^{\dagger 2}$, Silvia Kuhlmann ${ }^{1}$, Youming Zhang ${ }^{3}$ and \\ Rolf Müller*1,2
}

\begin{abstract}
Address: ${ }^{1}$ Institut für Pharmazeutische Biotechnologie, Universität des Saarlandes, Postfach 1511 50, D-66041 Saarbrücken, Germany, ${ }^{2}$ Helmholtz-Zentrum für Infektionsforschung GmbH, MWIS, Inhoffenstraße 7, D-38124 Braunschweig, Germany and ${ }^{3} \mathrm{Gene}$ Bridges GmbH, BioInnovationsZentrum, Tatzberg 47, 01307 Dresden, Germany
\end{abstract}

Email: Olena Perlova - o.perlova@mx.uni-saarland.de; Klaus Gerth - Klaus.Gerth@helmholtz-hzi.de; Silvia Kuhlmann - s.kuhlmann@mx.unisaarland.de; Youming Zhang - youming.zhang@genebridges.com; Rolf Müller* - rom@mx.uni-saarland.de

* Corresponding author †Equal contributors

Published: 6 January 2009

Microbial Cell Factories 2009, 8:I doi:10.1 186/1475-2859-8-1
Received: 20 October 2008

Accepted: 6 January 2009

This article is available from: http://www.microbialcellfactories.com/content/8/I/I

(C) 2009 Perlova et al; licensee BioMed Central Ltd.

This is an Open Access article distributed under the terms of the Creative Commons Attribution License (http://creativecommons.org/licenses/by/2.0), which permits unrestricted use, distribution, and reproduction in any medium, provided the original work is properly cited.

\begin{abstract}
Although many secondary metabolites with diverse biological activities have been isolated from myxobacteria, most strains of these biotechnologically important gliding prokaryotes remain difficult to handle genetically. In this study we describe the new fast growing myxobacterial thermophilic isolate GT-2 as a heterologous host for the expression of natural product biosynthetic pathways isolated from other myxobacteria. According to the results of sequence analysis of the $16 \mathrm{~S}$ rDNA, this moderately thermophilic isolate is closely related to Corallococcus macrosporus and was therefore named C. macrosporus GT-2. Fast growth of moderately thermophilic strains results in shorter fermentation and generation times, aspects which are of significant interest for molecular biological work as well as production of secondary metabolites. Development of a genetic manipulation system allowed the introduction of the complete myxochromide biosynthetic gene cluster, located on a transposable fragment, into the chromosome of GT-2. Genetic engineering of the biosynthetic gene cluster by promoter exchange leads to much higher production of myxochromides in the heterologous host $C$. macrosporus GT2 in comparison to the original producer Stigmatella aurantiaca and to the previously described heterologous host Pseudomonas putida $(600 \mathrm{mg} / \mathrm{L}$ versus $8 \mathrm{mg} / \mathrm{L}$ and $40 \mathrm{mg} / \mathrm{L}$, respectively).
\end{abstract}

\section{Background}

Although the world wide demand for novel anti-infectious agents is becoming more and more pressing, several pharmaceutical companies withdrew from "new antibiotic" research because of the long development times and the high financial risk. At the same time antibiotic resistance of numerous pathogenic organisms is increasing quickly. In addition, globalization and changes in socio- economic conditions increase the risk of a spread of currently unknown infectious microorganisms and agents [1]. During the last two decades, myxobacteria became widely known as valuable producers of secondary metabolites exhibiting various biological activities [2,3]. However, the optimization of production of the already known metabolites with promising biological activities like epothilones [4] or tubulysins $[5,6]$ remains a chal- 
lenging task. Myxobacteria are ubiquitous microorganisms which live on rotting plant material, animal dung and in soils worldwide [7-9]. These fascinating gram-negative bacteria are able to undergo a developmental life cycle including the formation of multicellular "fruiting bodies" upon starvation. The largest known myxobacterial strain collection exists at the Helmholtz Centre for Infection Research with about 7500 isolates including novel moderately thermophilic myxobacteria described by Gerth and Müller [8]. This group of thermophilic myxobacteria grows between $30^{\circ} \mathrm{C}$ and $48^{\circ} \mathrm{C}$, with a temperature optimum between $42^{\circ} \mathrm{C}$ and $44^{\circ} \mathrm{C}$. In contrast, the temperature optimum for the growth of other myxobacteria is between $30^{\circ} \mathrm{C}$ and $34^{\circ} \mathrm{C}$. Interestingly, moderately thermophilic myxobacteria grow faster than most other myxobacteria [8].

Most of the natural products produced by myxobacteria are polyketides, nonribosomally made peptides or hybrid compounds. The biosynthesis of these compounds is catalyzed by complex and multimodular polyketide synthases (PKS) or nonribosomal peptide synthetases (NRPS) comprising numerous domains which are responsible for each catalytic step in the corresponding biosyntheses starting from activated short chain carboxylic acids or amino acids [10]. To date, various PKS and NRPS biosynthetic gene clusters have been identified including several from myxobacteria, e.g. those directing the biosynthesis of the electron transport inhibitors myxothiazol and melithiazol $[11,12]$, the potential anticancer agents epothilones and tubulysins [13-15], the myxochromides [16], disorazols [17], chivosazols [18], myxovirescins [19] and some other natural products with antibacterial, antifungal or cytotoxic activities [20]. The available genome sequences showed that in most cases the genome of the producer organism encodes more biosynthetic gene clusters than mirrored by identified compounds. Therefore, the genetic potential to produce secondary metabolites is higher than originally expected due to so-called "silent" genes [21]. Whether these genes are indeed "silent" or the amount of produced compound is too low for detection is a matter of debate. In a recent study, we could show that 11 out of 18 biosynthetic gene clusters in M. xanthus DK1622 are indeed expressed and translated into proteins during vegetative growth although only five compounds are known from this strain [19,21-24]. A similar situation is obvious for Sorangium cellulosum So ce56, which also contains more genes potentially involved in the production of the secondary metabolism than expected after the isolation of the natural products from the culture extracts [21,24-26].

One of the possibilities to explore the genetic potential of such microorganisms or to deliberately modify natural product biosynthesis is the heterologous expression of the corresponding biosynthetic gene clusters. This is particularly useful if the manipulation of the chromosome in the producer strain is difficult, as in many myxobacterial strains.

This method allows to access the biosynthetic genes even from metagenome libraries of unculturable microorganisms if appropriate heterologous hosts are chosen $[27,28]$. Therefore, the development of heterologous expression systems for the transfer of large biosynthetic gene clusters from the natural producer strain into more suitable and easily culturable heterologous hosts is of great significance for natural product research [29].

In this work, we characterize Corallococcus macrosporus GT2 exemplarily for moderately thermophilic myxobacteria as heterologous hosts and describe the expression of the myxochromide megasynthetase based on a novel transposon gene cluster transfer strategy which also involved promoter exchange. Production of the natural product could be significantly increased from $8 \mathrm{mg} / \mathrm{L}$ in original producer $S$. aurantiaca to $600 \mathrm{mg} / \mathrm{L}$ in GT-2.

\section{Results and discussion Physiological properties of the isolate C. macrosporus GT-2}

Thermophilic myxobacteria with potential for the biosynthesis of natural products were isolated and described for the first time in 2005 by Müller and Gerth [8]. The idea to use thermophilic myxobacteria as heterologous hosts for the expression of diverse myxobacterial biosynthetic gene clusters arose with the physiological characterization of this novel group of bacteria, which exhibits very useful features such as fast growth in combination with typical myxobacterial properties such as social behaviour.

Here, we characterize a new thermophilic isolate of $C$. macrosporus as model host organism. Strain GT-2 is a moderately thermophilic myxobacterium which grows in yellow coloured swarm colonies. Fruiting bodies resemble those of Corallococcus and the myxospores are spherical and optically refractile. The vegetative cells are slender rods with tapering ends as they are typical for members of the suborder Cystobacterineae. As published previously C. macrosporus has a separate systematic position and is more closely related to $M$. xanthus than to the other members of Corallococcus [30].

The 16S rDNA of GT-2 was sequenced and submitted in the NCBI BLAST basic local alignment search tool to identify similar sequences. The moderately thermophilic isolate is closely related to C. macrosporus (98\% identity of the $16 \mathrm{~S}$ rDNA to the type strain C. macrosporus Cc $\mathrm{m} 8$, DSM 14697) and was therefore named C. macrosporus GT2. Like many nonadapted myxobacteria, C. macrosporus 
GT-2 initially grew in liquid medium in small cell aggregates. Therefore, the optimum growth temperature was determined in $15 \mathrm{l}$ bioreactors by growing the bacteria at different temperatures (Fig. 1a). In the cause of the fermentations the carbon dioxide concentrations in the

a)

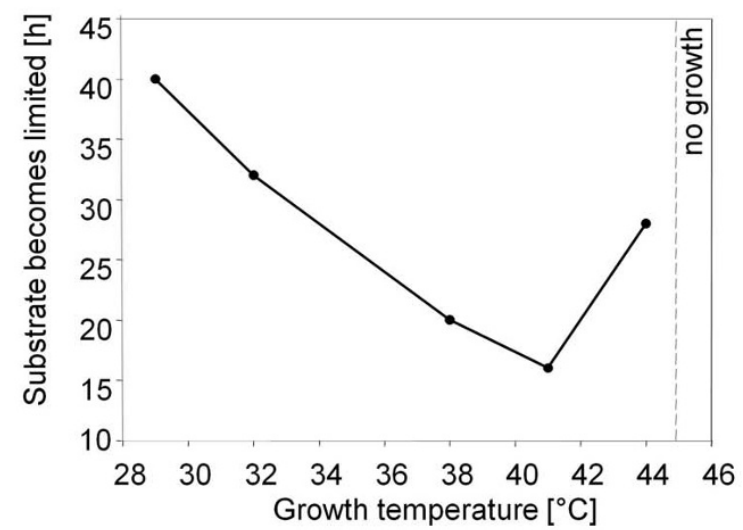

b)

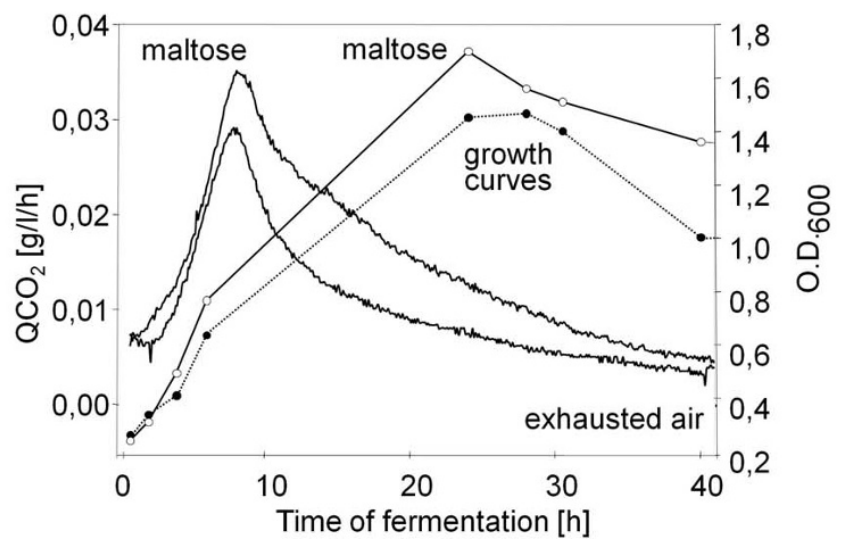

Figure I

a) The time required to reach substrate limitation is shown in dependence of the temperatures in 5 parallel fermentations. The $\mathrm{CO}_{2}$ concentration in the exhausted air increased in dependency of the cell number as a consequence of metabolism of the carbon source. The faster the growth velocity, the earlier the carbon source became limiting resulting in a drop in $\mathrm{CO}_{2}$ concentration measured in the exhausted air. The period of time to reach this turning point is an indirect measure for growth velocity. b) Effect of maltose on growth and $\mathrm{CO}_{2}$ liberation compared to a control fermentation without alternative carbon source. The $\mathrm{QCO}_{2}$ was determined by balancing the exhausted air (see curves of exhausted air) as described. Growth was determined by measuring the optical density (black circle $=$ control culture, open circle $=$ culture with maltose added). exhausted air were measured continuously (Fig. 1b). The time required to reach the turning points in carbon dioxide liberation $\left(\mathrm{CO}_{2}\right.$ production declines because the carbon source becomes limiting) is easily monitored (Fig. $1 b)$. This value can be used as a measure for growth velocity at the different temperatures (Fig. 1a).

With a temperature increase from $29^{\circ} \mathrm{C}$ to $41^{\circ} \mathrm{C}$ the time needed to reach substrate limitation decreased and increased again with a rise of temperature to $44^{\circ} \mathrm{C}$, which was the highest temperature tolerated by this strain. The optimum temperature is approximately $42^{\circ} \mathrm{C}$ which is typical for moderately thermophilic myxobacteria. With a calculated generation time of little more than 2 hours this isolate grows three times faster than mesothermophilic Myxococcus isolates [8].

Growth and production of secondary metabolites of Myxococcus strains are limited by their restriction to amino acids as sole carbon and energy sources. Ammonium accumulates and becomes inhibitory to growth [3]. Little information is available for Corallococcus strains on alternative carbon sources. According to results published previously [30], C. macrosporus assimilates glucose. In our experiments, we could not verfiy this result for the strain under study. In contrast, maltose slightly stimulated growth of the GT-2 strain (Fig. 1b). During fermentation experiments in $15 \mathrm{l}$ bioreactors, an effect of maltose was seen as an increase of the optical density, a higher maximum value in the produced $\mathrm{CO}_{2}$ and a slower drop during the following 30 hours of fermentation. In contrast to Myxococcus xanthus, GT-2 can use maltose as additional carbon source (under the given conditions about $7 \%$ consumption).

Salt concentrations of marine environments, about 3.2 to $3.8 \%$ of $\mathrm{NaCl}$, inhibited the growth of GT-2 but concentrations up to $2 \%$ were well tolerated and resulted in doubling of the generation time to 4 hours. Salt tolerance may be a useful trait for heterologous expression of biosynthetic gene clusters from marine strains $[27,31]$ because of possibly interconnected underlying regulatory processes.

Similar to most of the myxobacteria described before, $C$. macrosporus GT-2 was resistant against numerous antibiotics (Table 1) but the two commonly used selection markers kanamycin and oxytetracycline can be used representing an additional advantageous property of this strain.

\section{Development of a genetic manipulation system for GT2 and suitability of this strain as heterologous host}

In order to utilize GT-2 as a heterologous host, a genetic manipulation system for this strain had to be developed. As marker gene, a kanamycin resistance cassette was cho- 
Table I: The inhibitory effect of $50 \mu \mathrm{g} / \mathrm{ml}$ of the respective antibiotic was determined by measuring the diameter of the swarm colony on agar plates incubated for I week at $30^{\circ} \mathrm{C}$.

\begin{tabular}{|c|c|}
\hline Antibiotic & $\begin{array}{c}\text { Diameter of the colony } \\
{[\mathrm{mm}]}\end{array}$ \\
\hline control & 20 \\
\hline Ampicillin & 12 \\
\hline Bacitracin & 12 \\
\hline Cephalosporin & 13 \\
\hline Fusidic acid & 19 \\
\hline Gentamicin & 15 \\
\hline Hygromycin & 14 \\
\hline Kanamycin & 0 \\
\hline Kasugamycin & 7 \\
\hline Neomycin & 11 \\
\hline Oxytetracycline & 0 \\
\hline Polymyxin & 11 \\
\hline Spectionmycin & 15 \\
\hline Trimetoprim & 6 \\
\hline Thiostrepton & 21 \\
\hline
\end{tabular}

sen. Next, the possibility to integrate foreign DNA through homologous recombination was analyzed. As a target for homologous recombination a DNA fragment from the GT-2 chromosome was amplified using degenerate PCR primers targeting fragments of $\beta$-ketoacyl-ACP synthase (KS) domains of polyketide synthases [32]. The resulting DNA fragment was cloned into the pCR2.1TOPO ${ }^{\circledast}$ cloning vector (Invitrogen) and sequenced to analyze the cloned PKS region. Subsequently, the resulting plasmid pOPB32 was introduced into the cells by electroporation. Different protocols were examined including the variation of such parameters as growth temperature of the cells prior to the preparation of competent cells, composition of washing and electroporation buffers, different voltage and pulse length as well as the incubation time after electroporation and the composition of the plating medium. Colony PCR was used as a method to screen for correct integrations of the suicide plasmid into the chromosome (data not shown).
Therefore, C. macrosporus GT-2 is the first strain from the collection of thermophilic myxobacteria for which a genetic manipulation system has been established.

Although no secondary metabolites could be isolated from GT-2 extracts derived from a set of growth conditions (including the variation of temperature; data not shown), the strain possesses genes encoding PKS which therefore seem to be "silent" under the tested laboratory conditions. This underscores the fact that the biosynthetic machinery for the biosynthesis of the heterologous product is available in the strain and at the same time the purification of the obtained product should be easier because it is not mixed with other produced metabolites.

Different techniques and strategies have been used for the heterologous expression with the aim to improve the yield of the natural product [29]. In general, the heterologous expression in phylogenetically related hosts is regarded most effective as they provide additional useful features such as similar GC content and a codon usage like in the donor strain. Also, other intracellular factors which influence heterologous expression [33] and affect stability of large transcripts, translational processivity of the long ORFs and protein folding are most likely available for the expression of biosynthetic genes in closely related strains. Another myxobacterium - M. xanthus - has already been used as a heterologous host for the biosynthesis of secondary metabolites from other myxobacterial species, e.g. epothilone from S. cellulosum [34], myxothiazol from S. aurantiaca [35] and myxochromide from $S$. aurantiaca [36]. However, GT-2 may in the future turn out to be an advantageous host for the reasons mentioned above and due to the fact that it grows two to three times faster than the well established M. xanthus.

\section{Integration of the myxochromide gene cluster into the chromosome of GT-2}

The biosynthetic genes encoding the myxochromide $\mathrm{S}$ megasynthetase in $S$. aurantiaca DW4/3-1 have been cloned, sequenced and modified for heterologous expression in Pseudomonas putida previously [16,37]. Subsequently, a transposon containing the whole myxochromide biosynthetic gene cluster as transposable element was constructed [36]. The transposon harbouring the constitutive $\mathrm{P}_{\text {aphII }}$ promoter driving the transcription of the myxochromide genes is shown in Figure 2. In contrast, the inducible Pm promoter was used to control expression in P. putida [37].

The integration of the plasmid pOPB32 into the chromosome of GT-2 followed by selection for the kanamycin resistance derived from the aphII gene verified that the promoter $\mathrm{P}_{\text {aphII }}$ is also active in this strain. 


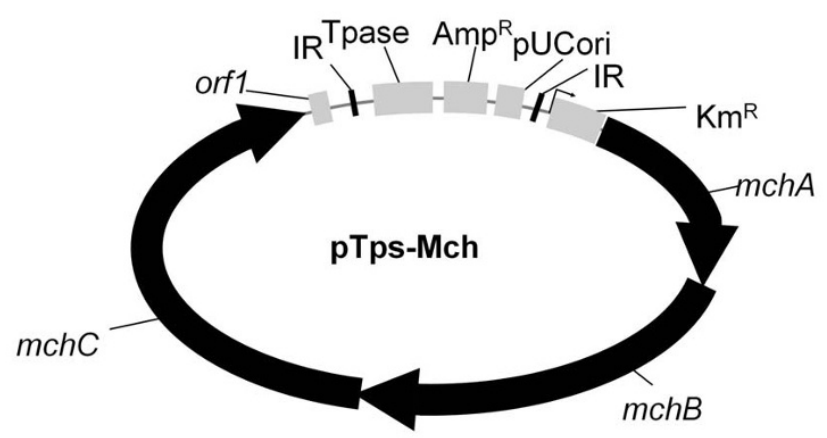

Figure 2

Construct used for integration into the chromosome of C. macrosporus GT-2. IR - inverted repeats; Tpase transposase; $\mathrm{PUC}$ ori - origin of replication; $A m p^{R}-$ ampicillin resistance selection marker; $\mathrm{Km}^{\mathrm{R}}$ - kanamycin resistance selection marker; right-angled arrow () $-\mathrm{P}_{a p h l l}$ Promoter; mchA-mchC - myxochromide biosynthetic genes; orfI - gene with unknown function located adjacent to the mch genes (Fu et al., 2008).

After electroporation kanamycin resistant colonies were obtained on the agar plates 2-3 days after incubation at $37^{\circ} \mathrm{C}$. Ten randomly chosen colonies were analyzed by colony PCR (s. Experimental procedures). PCR analysis showed amplificates of the expected size of 593 bp and 700 bp, respectively and thus verified the successful transposition and integration of the myxochromide gene cluster into the chromosome (data not shown). As expected, the mutants containing the myxochromid biosynthetic gene cluster under the control of $\mathrm{P}_{a p h I I}$ promoter produced the corresponding compound myxochromide $S$ plus its derivatives constitutively (Fig. 3, 4.).

\section{Analysis of the myxochromide production}

Culture extracts of the mutant strains were investigated by HPLC analysis after growth at $30^{\circ} \mathrm{C}$. It was possible to identify myxochromides S1-3 synthesized by the gene products of the cloned mch gene cluster from $S$. aurantiaca as well as additional myxochromide derivatives (Fig. 3a). Myxochromide S3 could be detected only in traces and could not be used for the quantification of total production yields. Additional peaks may represent derivatives of S1 and S2 lacking methyl groups as has been assumed also for the novel heterologous myxochromide derivatives in P. putida [37].

HPLC analysis showed that the tested mutants, which contain mch genes in the chromosome, differed in their ability to produce myxochromides relative to each other. The analysis of the integration position of the transposable element showed that the myxochromide biosynthetic genes, as expected, have been integrated into different chromosomal loci of the GT-2 genome (Table 2). The mutant strain producing the highest amount of myxo- a)

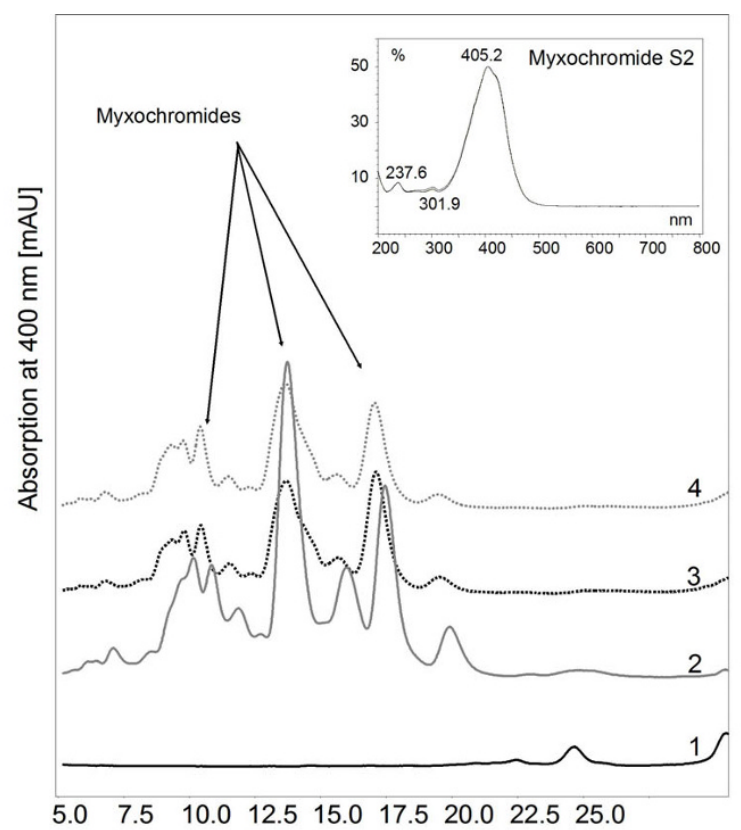

b)

Time [min]

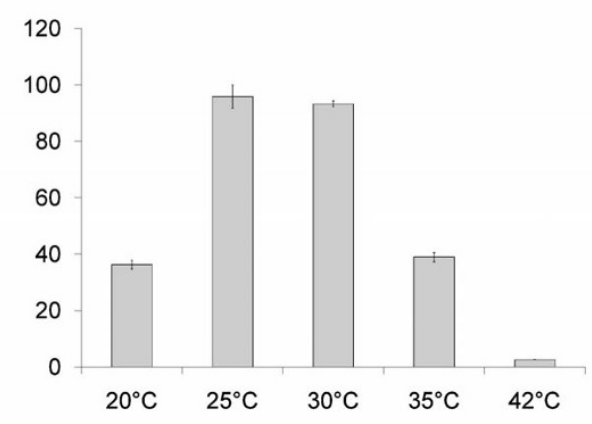

Figure 3

Myxochromide production in C. macrosporus GT2::mch a) HPLC-DAD (diode array detector) chromatogram: I - extract of C. macrosporus GT-2; 2 - 4 extracts of mutant strains containing the myxochromide gene cluster integrated into the chromosome of GT-2. Inset panel: UV spectrum of myxochromide $S$ at $400 \mathrm{~nm}$. b) Influence of the temperature on the heterologous myxochromide production in C. macrosporus GT-2::mch.

chromide in comparison to other mutants was named $C$. macrosporus GT-2::mch and used for further studies.

In order to find optimal conditions for the heterologous myxochromide production first the influence of the temperature on the production was examined. The cultures were incubated at different temperatures from $20^{\circ} \mathrm{C}$ to $42^{\circ} \mathrm{C}$ for 3 days and the production of myxochromides was compared. Interestingly, almost no production could be detected in cultures which were grown at $42^{\circ} \mathrm{C}$. While the optimal growth temperature for GT- 2 is $42^{\circ} \mathrm{C}$ (Fig. $1 \mathrm{a})$, the most favourable temperature for heterologous 

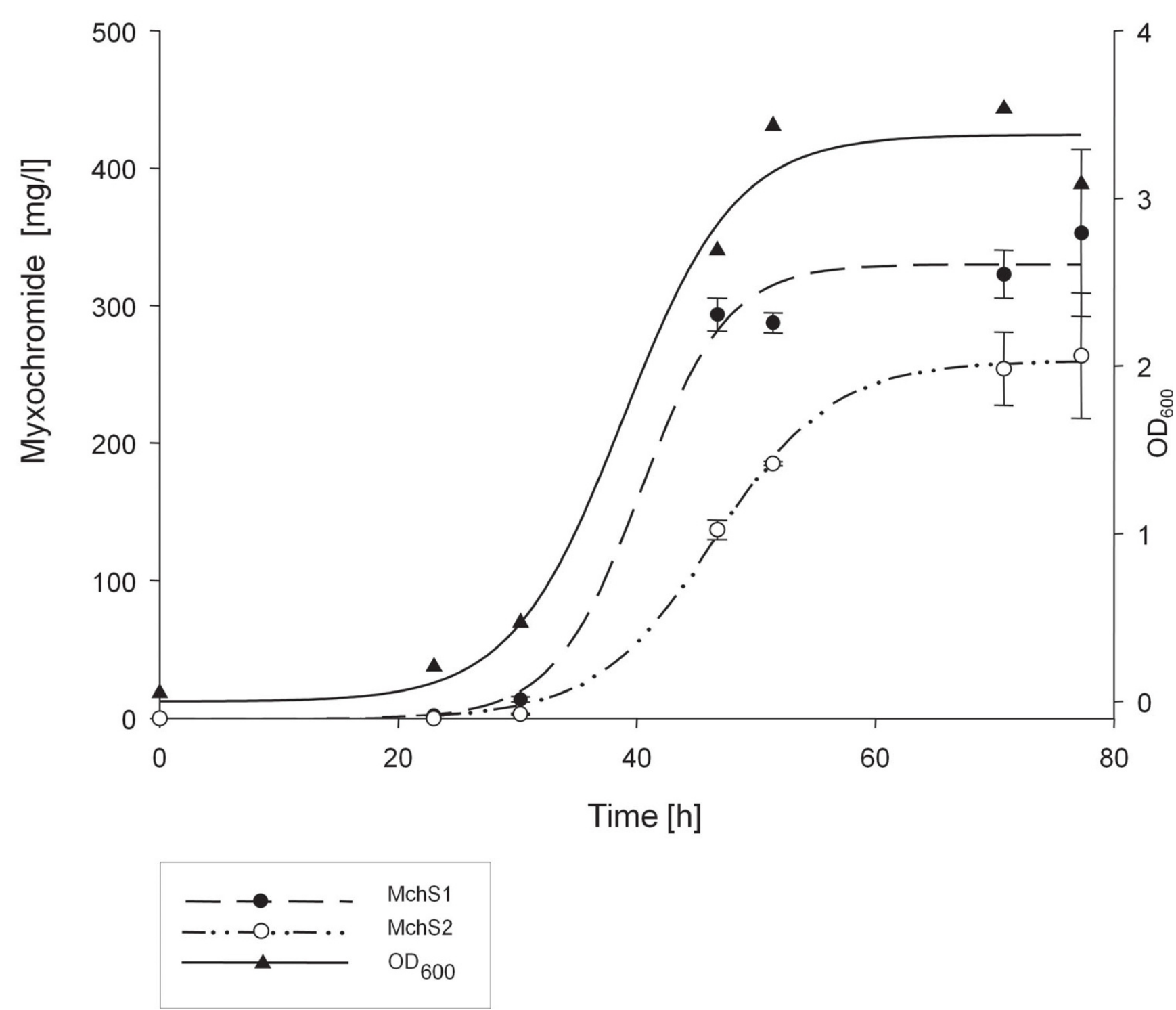

Figure 4

Production kinetics of myxochromides SI and S2 in C. macrosporus GT-2::mch at $30^{\circ} \mathrm{C}$.

myxochromide production was found to be $25-30^{\circ} \mathrm{C}$ (Fig. 3b).

Although it could already be shown for other secondary metabolite producers that product formation is dependent on temperature and in many cases increases with lower temperatures even in natural producer strains, e.g. phaseolotoxin production by Pseudomonas syringae pv. phaseolicola [38] or phenazine production by $P$. fluorescens 2-79 [39], the highest level of production of different secondary metabolites in thermophilic myxobacteria, e.g. myxothiazols, phenalamids and stigmatellins, has been detected at the optimal growth temperature of $42^{\circ} \mathrm{C}$ [8]. For the heterologous biosynthesis of myxochromides in
GT-2 the expression of foreign proteins (PKS and NRPS) itself might be stressful and lower temperatures might reduce protein misfolding by slowing down transcription and translation rates, especially in cases when the proteins are expressed from strong promoters (such as $\mathrm{P}_{\text {aphII }}$ in our case) as has been described in E. coli $[40,41]$. Interestingly, the expression of the kanamycin resistance gene occurred even at higher temperature and allowed the selection of the kanamycin resistant mutants already after 2 days of growth on the agar plates. This is highly advantageous because $M$. xanthus, another heterologous expression host, requires 5-10 days for the growth on selection plates. 
Table 2: Integration sites of myxochromide biosynthetic genes in C. macrosporus GT-2.

\begin{tabular}{|c|c|c|c|}
\hline \multicolumn{3}{|c|}{ DNA sequence } & \multirow[b]{2}{*}{ Organism, Identity, \% } \\
\hline Mutant clone & IR (underlined) insertion site (bold italic) & Gene product & \\
\hline GT2::mch & $\begin{array}{l}\text { AGCGTGAAGACCGGGGACTTATCAGCCA } \\
\text { ACCTGTTA } \\
\text { GTTGGAGAGCGAGACGACGACGAGCT--- }\end{array}$ & $\begin{array}{l}\text { NADP } \\
\text { oxidoreductase }\end{array}$ & Myxococcus xanthus DKI622, 91 \\
\hline PI & $\begin{array}{l}\text { AGCGTGAAGACCGGGGACTTATCAGCCA } \\
\text { ACCTGTTA } \\
\text { CACCTGTGCAGCCGGGCTCACCCCGG--- }\end{array}$ & Hypothetical protein & Myxococcus xanthus DKI622, 79 \\
\hline P2 & $\begin{array}{l}\text { AGCGTGAAGACCGGGGACTTATCAGCCA } \\
\text { ACCTGTTA } \\
\text { GATGGCGCTGACGCGAATGATGACCT--- }\end{array}$ & $\begin{array}{l}\text { site-specific recombinase, phage integrase } \\
\text { family protein }\end{array}$ & Mycobacterium avium 104, 31 \\
\hline P3 & $\begin{array}{l}\text { AGCGTGAAGACCGGGGACTTATCAGCCA } \\
\text { ACCTGTTA } \\
\text { GCCCAGGCCCGCTTCACCGCCAATGG--- }\end{array}$ & Predicted transcriptional regulator & $\begin{array}{l}\text { Magnetospirillum magneticum } \\
\text { AMB-I, } 60\end{array}$ \\
\hline P5 & $\begin{array}{l}\text { AGCGTGAAGACCGGGGACTTATCAGCCA } \\
\text { ACCTGTTA } \\
\text { GTCATGGACCTCCGTGACGGTGCCCA--- }\end{array}$ & $\begin{array}{l}\text { excinuclease } A B C \text {, } \\
\text { A subunit }\end{array}$ & Myxococcus xanthus DKI622, 98 \\
\hline P6 & $\begin{array}{l}\text { AGCGTGAAGACCGGGGACTTATCAGCCA } \\
\text { ACCTGTTA } \\
\text { CGTGCCCATCGACGCCTCACCGGCGA--- }\end{array}$ & hydrolase, CocE/NonD family & Myxococcus xanthus DKI622, 72 \\
\hline
\end{tabular}

Kinetic studies of myxochromide production were carried out at $30^{\circ} \mathrm{C}$. The production correlated with the number of cells in the culture, so the maximum of production and a constant amount of the product was reached with the stationary phase of the culture. The production maximum was reached after 2 days, compared to 6 days required when using $S$. aurantiaca. GT-2 produced approximately $350 \mathrm{mg} / \mathrm{L}$ myxochromide $\mathrm{S} 1$ and $250 \mathrm{mg} / \mathrm{L}$ myxochromide S2 (Fig. 4). The product yield of just the major compounds S1 and S2 was thus larger than $600 \mathrm{mg} / \mathrm{L}$ and therefore much higher than in the original producer $S$. aurantiaca $(8 \mathrm{mg} / \mathrm{L}$ total) and in the previously described heterologous host $P$. putida (40 mg/L total) [37] although in recently described studies of heterologous production of myxochromides in $M$. xanthus production of about $1 \mathrm{~g} /$ L could be shown [36].

\section{Transposon based integration of secondary metabolite biosynthetic genes allows screening for alternative heterologous hosts}

Recently, we described the advantages of Red/ET recombineering for the generation of constructs for the integration into heterologous hosts $[35,37,42]$. For the expression of the myxothiazol gene cluster the construct containing homologous regions for integration either into M. xanthus or $P$. putida was introduced into the vector containing all myxothiazol biosynthetic genes. The disadvantage of this strategy is the requirement of the introduction of different homologous chromosomal targets for each heterologous host strain. In this study, we used a transposon based strategy which can be employed in a very flexible way for the introduction of the same construct into different heterologous hosts in parallel experiments to investigate the suitability of different hosts and conditions for metabolite production.

With the described transposon based strategy the myxochromide biosynthetic genes were successfully integrated into already described heterologous host strains - M. xanthus and P. putida [36].

The approach described here might be especially useful in the future for the expression of silent biosynthetic gene clusters [21] which can be activated by inserting promoters constitutively active in a variety of host strains. Moreover, our studies showed that C. macrosporus GT-2 may be 
developed into a very useful heterologous host for myxobacterial secondary metabolite production in the future.

\section{Methods}

Isolation of GT-2

The method for the isolation of moderately thermophilic myxobacteria has been described previously in detail [8] GT-2 was isolated from a soil sample from Sousse (Tunesia).

\section{Media (constituents in g/l) and maintainance of liquid cultures}

Medium M: Soy peptone (Marcor), 10; Maltose; 10: $\mathrm{CaCl}_{2}$ $\times 2 \mathrm{H}_{2} \mathrm{O}, 1 ; \mathrm{MgSO}_{4} \times 7 \mathrm{H}_{2} \mathrm{O}, 1$; HEPES, 11.9; Fe-EDTA, 8 mg; $\mathrm{pH}$ adjusted to 7.2 .

Basic fermentation medium: Soy peptone (Marcor), 5; $\mathrm{CaCl}_{2} \times 2 \mathrm{H}_{2} \mathrm{O}, 1 ; \mathrm{MgSO}_{4} \times 7 \mathrm{H}_{2} \mathrm{O}, 1 ; \mathrm{Fe}-\mathrm{EDTA}, 8 \mathrm{mg}$; $\mathrm{ZnCl}_{2}, 1 \mathrm{mg} ; \mathrm{K}_{2} \mathrm{HPO}_{4}$ 0,1 g; $\mathrm{pH}$ adjusted to 7.2.

Liquid cultures were started by inoculating $100 \mathrm{ml}$ of medium $\mathrm{M}$ in $250 \mathrm{ml}$ erlenmeyer flasks with $5 \mathrm{ml}$ of precultures. Inoculated flasks were incubated at $42^{\circ} \mathrm{C}$ on a rotary shaker at $160 \mathrm{rpm}$ for 4 days.

\section{Fermentation conditions}

Basic fermentation medium: Soy peptone (Marcor), 5; $\mathrm{CaCl}_{2} \times 2 \mathrm{H}_{2} \mathrm{O}, 1 ; \mathrm{MgSO}_{4} \times 7 \mathrm{H}_{2} \mathrm{O}, 1$; Fe-EDTA, $8 \mathrm{mg}$; $\mathrm{ZnCl}_{2}, 1 \mathrm{mg} ; \mathrm{K}_{2} \mathrm{HPO}_{4} 0,1 \mathrm{~g}$; $\mathrm{pH}$ adjusted to 7.2.

Fermentations were performed in $15 \mathrm{l}$ bioreactors (Fermenter B10, Fa. Biologische Verfahrenstechnik) with $10 \mathrm{l}$ of fermentation medium inoculated with $1 \mathrm{l}$ of a preculture grown under shaking $(160 \mathrm{rpm})$ in the same medium. The fermentations were run at $29^{\circ} \mathrm{C}, 32^{\circ} \mathrm{C}$, $38^{\circ} \mathrm{C}, 41^{\circ} \mathrm{C}, 44^{\circ} \mathrm{C}$ and at $45^{\circ} \mathrm{C}$ with an aeration of 0.1 vvm (volumes of air per minute per volume of batch culture). A pH of 7.0 was maintained by the addition of $5 \%$ sulphuric acid.

Dissolved oxygen was measured with a polarographic stream sterilizable dissolved oxgygen electrode (Ingold). $\mathrm{A} \mathrm{pO}_{2}$ of $40 \%$ was maintained by regulation of the stirrer speed. The exhausted air was measured in a continuous gas analyser (H. Maihak AG, Hamburg equipped with unor $-\mathrm{CO}_{2}$ analyser and oxor -oxygen analyser).

\section{Test for effects of carbohydrates on growth}

The effect of maltose on growth was investigated in the basic fermentation medium with additional $10 \mathrm{~g} / \mathrm{l}$ of maltose and $0.25 \mathrm{~g} / \mathrm{l}$ of ammonium sulfate. Growth at $42^{\circ} \mathrm{C}$ was followed by measuring of the optical density (O.D.) at $600 \mathrm{~nm}$ and the carbon dioxide production.

\section{Calculation of the generation time}

Growth in medium $\mathrm{M}$ at $42{ }^{\circ} \mathrm{C}$ was analyzed every 2 hours by counting the cell number in a counting cell (Neubauer improved, 0,02 mm depth; $0,0025 \mathrm{~mm}^{2}$ ). The generation time was calculated by the following equation: $\mathrm{g}=\lg 2 \times \mathrm{t} /$ $\lg \mathrm{N}_{1}-\lg \mathrm{N}_{0}(\mathrm{~g}=$ generation time; $\mathrm{t}=$ time of incubation; $\mathrm{N}$ is the mean value of the cell number at time 0 and time 1 )

\section{Growth in the presence of $\mathrm{NaCl}$}

The effect of sodium chloride was investigated in $100 \mathrm{ml}$ medium $\mathrm{M}$ in $250 \mathrm{ml}$ Erlenmeyer flasks in the presence of increasing concentrations of $\mathrm{NaCl}$. For the determination of the generation time the following medium was used: marine broth (Difco), $37.4 \mathrm{~g} / \mathrm{l}$; peptone (Marcor typ S), 5 $\mathrm{g} / \mathrm{l}$; HEPES buffer, $100 \mathrm{mM}$, pH 7.4.

\section{Antibiotic resistance}

After autoclaving of the agar medium $\mathrm{M}$, antibiotics were added to a final concentration of $50 \mu \mathrm{g} / \mathrm{ml}$. The plates were incubated at $30^{\circ} \mathrm{C}$. After 1 week the diameter of the swarm colonies was measured as an indication of growth.

\section{Analysis of maltose content}

Culture broths of the fermentations were analysed twice a day for the maltose content. After centrifugation for 30 min at $10.000 \mathrm{rpm}$ in a Sorvall cool centrifuge, $20 \mu \mathrm{l}$ of the supernatant was mixed with $177 \mu$ of distilled water and $3 \mu \mathrm{l}$ of a $\alpha$-glucosidase solution. After incubation for $1 \mathrm{~h}$ at $37^{\circ} \mathrm{C}$ the reaction solution was incubated at $80^{\circ} \mathrm{C}$ for $15 \mathrm{~min}$ and centrifuged again. The supernatant was diluted 1:10 with distilled water and the glucose concentration was analysed with a hexokinase test kit (Boehringer Mannheim).

\section{Sequencing of the I6S rDNA from GT-2}

A fragment was generated by PCR (Taq DNA polymerase), using genomic DNA as template and the primers SB19 and SB20 [43] The PCR fragment was cloned using the TOPO TA cloning kit (Invitrogen). The insert of the resulting plasmid was sequenced and compared with the NCBI data bank.

\section{Electroporation into C. macrosporus GT-2}

The GT-2 cells were grown in liquid medium $\mathrm{M}$ at $30^{\circ} \mathrm{C}$ to a final cell density of $10^{9}$ cells $/ \mathrm{ml}$. After centrifugation and washing with washing buffer ( $1 \mathrm{mM}$ HEPES, $0.5 \%$ glucose, $\mathrm{pH} 7.4$ ), cells were resuspended in $1 \mathrm{ml}$ of electroporation medium $\left(0.5 \%\right.$ glucose in distilled $\left.\mathrm{H}_{2} \mathrm{O}\right)$ to $10^{10}$ cells $/ \mathrm{ml}$. The cell suspension $(100 \mu \mathrm{l})$ was mixed with up to $1 \mu \mathrm{g}$ of DNA and electroporated (BioRad electroporator) at $25 \mu \mathrm{F}, 1200 \mathrm{~V}(\tau=5 \mathrm{~ms})$ using $0.1 \mathrm{~cm}$ cuvette. After electroporation $900 \mu \mathrm{l}$ medium was added, then the cells were resuspended in $10 \mathrm{ml} \mathrm{M}$ medium and the Erlenmeyer flasks were incubated at 
$37^{\circ} \mathrm{C}$ or at $42^{\circ} \mathrm{C}$ on a rotary shaker at $160 \mathrm{rpm}$ overnight. After centrifugation the cells were resuspended in $1 \mathrm{ml}$ liquid $\mathrm{M}$ medium and different cell dilutions were plated for selection on $\mathrm{M}$ agar plates (medium $\mathrm{M}$ with $1.5 \%$ agar) supplemented with $50 \mu \mathrm{g} / \mathrm{ml}$ kanamycin. The kanamycin resistant colonies arising after $2-3$ days at $42^{\circ} \mathrm{C}$ were tested for growth in liquid medium. Integration of the marker gene was verified by colony PCR with different primers specific for the integrated DNA.

\section{Analysis of the integration of the myxochromide biosynthetic gene cluster}

The transposon used in this study is shown in Figure 2[36]. After electroporation the mutants were analyzed by colony PCR for the integration of the myxochromide biosynthetic gene cluster into the chromosome using two primer pairs: Mch35 and Mch36 [37], and Mch3 (5'-CAAGACGGCCACAGTGAGTCGATGAC) and Mch4 (5'CAAGCGCGCGAAGCGCCTCGGGGC) amplifying 700 bp and 593 bp fragments of the myxochromide biosynthetic genes, respectively. The mutant strain containing the myxochromide biosynthetic gene cluster and producing highest amount of myxochromide in comparison to other mutants was named C. macrosporus GT-2::mch and used for further studies.

In order to identify the insertion sites of the mch gene cluster in GT-2 strain the chromosomal DNA from 6 different mutants was analyzed. For this purpose a two-step procedure has been applied. The first step was a single-primer PCR (5'-gcaattccggttcgcttgct) based on the rapid amplification of transposon ends (RATE) protocol [44]. For the second step - sequencing - the additional nested primer (5'ccagtagctgacattcatcc) was used. The preceeding PCR was performed as a three-step, single-primer PCR. The first and third steps were performed at stringent temperature whereas the second step was performed at low temperature $\left(30^{\circ} \mathrm{C}\right)$. After initial denaturation for $5 \mathrm{~min}$ at $95^{\circ} \mathrm{C}$ 30 cycles of amplification were performed: $30 \mathrm{~s}$ at $95^{\circ} \mathrm{C}$, $30 \mathrm{~s}$ at $55^{\circ} \mathrm{C}$ and $30 \mathrm{~s}$ at $72^{\circ} \mathrm{C}$. The second step included 30 cycles: $30 \mathrm{~s}$ at $95^{\circ} \mathrm{C}, 30 \mathrm{~s}$ at $30^{\circ} \mathrm{C}$ and $30 \mathrm{~s}$ at $72^{\circ} \mathrm{C}$. The last step included 30 cycles as in first step followed by a final extension at $72^{\circ} \mathrm{C}$ for $10 \mathrm{~min}$. In the first step the single-stranded products were generated, which were then amplified in a second step at low temperature with nonspecific binding of the same primer. The third step amplified specific and non-specific products at stringent temperature. PCR reactions were purified and sequenced with specific nested primers. The results are shown in Table 2.

\section{HPLC-MS analysis of myxochromide production}

Fifty $\mathrm{ml}$ medium $\mathrm{M}$ in a $300 \mathrm{ml}$ flask was inoculated with $2.5 \mathrm{ml}$ of an overnight culture of strain GT-2::mch and XAD 16 (Rohm und Haas, Frankfurt, 2\%) was added routinely. After 3 days of incubation with shaking at the tem- peratures given in Results and discussion the cells were harvested by centrifugation and extracted with acetone and methanol. The extracts were evaporated and dissolved in $1 \mathrm{ml}$ methanol. $5 \mu \mathrm{l}$ of the extracts were analyzed by HPLC (Dionex solvent delivery system coupled to PDA100 Photodiode Array Detector).

The detection was carried out at $400 \mathrm{~nm}$. For quantification the extracts were prepared from $1 \mathrm{ml}$ culture and analyzed by LC-MS (Agilent 1100 series, Bruker HCT plus Ion Trap mass spectrometer). The chromatographic conditions used were: RP column Nucleodur C18 (MachereyNagel), $125 \times 2 \mathrm{~mm}, 3 \mu \mathrm{m}$, and precolumn C18, $8 \times 3$ $\mathrm{mm}, 5 \mu \mathrm{m}$. A solvent gradient (using solvent A and B with solvent A being water plus $0.1 \%$ formic acid, and solvent $\mathrm{B}$ being acetonitrile plus $0.1 \%$ formic acid) from $60 \% \mathrm{~B}$ at $1 \mathrm{~min}$ to $95 \% \mathrm{~B}$ within $6 \mathrm{~min}$ was applied and followed by $2 \mathrm{~min}$ at $95 \% \mathrm{~B}$. The myxochromides were identified by comparison to the retention times and the MS fragmentation pattern of the authentic reference substances (parent ions are given: myxochromide $\mathrm{S} 1$ : $[\mathrm{M}+\mathrm{H}]^{+}=723$; myxochromide $\mathrm{S} 2:[\mathrm{M}+\mathrm{H}]^{+}=737 ;$ myxochromide S3: $\left.[\mathrm{M}+\mathrm{H}]^{+}=749\right)$.

\section{Abbreviations}

IR: inverted repeat; kbp: kilobase pair; ORF: open reading frame.

\section{Competing interests}

The authors declare that they have no competing interests.

\section{Authors' contributions}

OP transformed GT-2, analyzed the production kinetics and drafted the manuscript. KG isolated and characterized GT-2 and participated in writing of the manuscript. SK participated in the molecular biological studies. YZ participated in the design of the study. RM coordinated the study and wrote the manuscript. All authors read and approved the final manuscript.

\section{Acknowledgements}

We thank Diana Telkemeyer for outstanding technical assistance, $\mathrm{H}$. Schüler for help with fermentations and Daniel Krug and Silke C. Wenzel for the analysis of myxochromide production. The work described here was supported by the Bundesministerium für Bildung und Forschung $(\mathrm{BMB}+\mathrm{F})$.

\section{References}

I. Sipahi OR: Economics of antibiotic resistance. Expert Review of Anti-Infective Therapy 2008, 6:523-539.

2. Reichenbach $\mathrm{H}$, Höfle $\mathrm{G}$ : Myxobacteria as producers of secondary metabolites. In Drug Discovery from Nature Edited by: Grabley S, Thiericke R. Berlin: Springer; 1999:149-179.

3. Gerth K, Pradella S, Perlova O, Beyer S, Müller R: Myxobacteria: Proficient producers of novel natural products with various biological activities - past and future biotechnological aspects with the focus on the genus Sorangium. J Biotechnol 2003, I06:233-253. 
4. Höfle G, Reichenbach H: Epothilone, a myxobacterial metabolite with promising antitumor activity. In Anticancer agents from natural products Edited by: Cragg GM, Kingston DG, Newman DJ. Boca Raton: Taylor \& Francis; 2005:4| 3-450.

5. Sasse F, Steinmetz H, Heil J, Höfle G, Reichenbach H: Tubulysins, new cytostatic peptides from myxobacteria acting on microtubuli: Production, isolation, physico-chemical and biological properties. J Antibiot 2000, 53:879-885.

6. Khalil MW, Sasse F, Lunsdorf H, Elnakady YA, Reichenbach H: Mechanism of action of tubulysin, an antimitotic peptide from myxobacteria. ChemBioChem 2006, 7:678-683.

7. Dawid W: Biology and global distribution of myxobacteria in soils. FEMS Microbiol Rev 2000, 24:403-427.

8. Gerth K, Müller R: Moderately thermophilic myxobacteria: Novel potential for production of natural products. Environ Microbiol 2005, 7:874-880.

9. lizuka T, Jojima Y, Fudou R, Yamanaka S: Isolation of myxobacteria from the marine environment. FEMS Microbiol Lett 1998, 169:317-322.

10. Fischbach MA, Walsh CT: Assembly-line enzymology for polyketide and nonribosomal Peptide antibiotics: logic, machinery, and mechanisms. Chem Rev 2006, I06:3468-3496.

II. Silakowski B, Schairer HU, Ehret H, Kunze B, Weinig S, Nordsiek G, Brandt P, Blöcker H, Höfle G, Beyer S, Müller R: New lessons for combinatorial biosynthesis from myxobacteria: the myxothiazol biosynthetic gene cluster of Stigmatella aurantiaca DW4/3-I. J Biol Chem 1999, 274:37391-37399.

12. Weinig S, Hecht HJ, Mahmud T, Müller R: Melithiazol biosynthesis: further insights into myxobacterial PKS/NRPS systems and evidence for a new subclass of methyl transferases. Chem Biol 2003, 1 0:939-952.

13. Julien B, Shah S, Ziermann R, Goldman R, Katz L, Khosla C: Isolation and characterization of the epothilone biosynthetic gene cluster from Sorangium cellulosum. Gene 2000, 249:153-160.

14. Molnar I, Schupp T, Ono M, Zirkle R, Milnamow M, Nowak-Thompson B, Engel N, Toupet C, Stratmann A, Cyr DD, Gorlach J, Mayo JM, Hu A, Goff S, Schmid J, Ligon JM: The biosynthetic gene cluster for the microtubule-stabilizing agents epothilones $A$ and $B$ from Sorangium cellulosum So ce90. Chem Biol 2000, 7:97-109.

15. Sandmann A, Sasse F, Müller R: Identification and analysis of the core biosynthetic machinery of tubulysin, a potent cytotoxin with potential anticancer activity. Chem Biol 2004 I I:1071-1079.

16. Wenzel SC, Kunze B, Höfle G, Silakowski B, Scharfe M, Blöcker H, Müller R: Structure and biosynthesis of myxochromides SI-3 in Stigmatella aurantiaca: Evidence for an iterative bacterial type I polyketide synthase and for module skipping in nonribosomal peptide biosynthesis. ChemBioChem 2005, 6:375-385.

17. Kopp M, Irschik H, Pradella S, Müller R: Production of the tubulin destabilizer disorazol in Sorangium cellulosum: biosynthetic machinery and regulatory genes. ChemBioChem 2005, 6:1277-1286.

18. Perlova O, Gerth K, Hans A, Kaiser O, Müller R: Identification and analysis of the chivosazol biosynthetic gene cluster from the myxobacterial model strain Sorangium cellulosum So ce56. | Biotechnol 2006, I 2 I:|74-191.

19. Simunovic V, Zapp J, Rachid S, Krug D, Meiser P, Müller R: Myxovirescin biosynthesis is directed by hybrid polyketide synthases/nonribosomal peptide synthetase, 3-hydroxy-3methylglutaryl CoA synthases and trans-acting acyltransferases. ChemBioChem 2006, 7:1206-1220.

20. Bode $H B$, Müller R: Analysis of myxobacterial secondary metabolism goes molecular. J Ind Microbiol Biotechnol 2006, 33:577-588

21. Bode HB, Müller R: The impact of bacterial genomics on natural product research. Angew Chem Int Ed 2005, 44:6828-6846.

22. Meiser P, Bode HB, Müller R: DKxanthenes: Novel secondary metabolites from the myxobacterium Myxococcus xanthus essential for sporulation. P Natl Acad Sci USA 2006, 103:19128-19133.

23. Schley C, Altmeyer MO, Swart R, Müller R, Huber CG: Proteome analysis of Myxococcus xanthus by off-line two-dimensional chromatographic separation using monolithic poly-(styrenedivinylbenzene) columns combined with ion-trap tandem mass spectrometry. J Proteome Res 2006, 5( I 0):2760-2768.
24. Wenzel SC, Meiser P, Binz T, Mahmud T, Müller R: Nonribosomal peptide biosynthesis: Point mutations and module skipping lead to chemical diversity. Angew Chem Int Ed 2006, 45:2296-230I.

25. Gaitatzis N, Kunze B, Müller R: Novel insights into siderophore formation in myxobacteria. ChemBioChem 2005, 6:365-374.

26. Schneiker S, Perlova O, Kaiser O, Gerth K, Alici A, Altmeyer MO, Bartels D, Bekel T, Beyer S, Bode E, Bode HB, Bolten CJ, Choudhuri JV, Doss S, Elnakady YA, Frank B, Gaigalat L, Goesmann A, Groeger C, Gross F, Jelsbak L, Jelsbak L, Kalinowski J, Kegler C, Knauber T, Konietzny S, Kopp M, Krause L, Krug D, Linke B, Mahmud T, Martinez-Arias R, McHardy AC, Merai M, Meyer F, Mormann S, MunozDorado J, Perez J, Pradella S, Rachid S, Raddatz G, Rosenau F, Ruckert C, Sasse F, Scharfe M, Schuster SC, Suen G, Treuner-Lange A, Velicer G], Vorholter FJ, Weissman KJ, Welch RD, Wenzel SC, Whitworth DE, Wilhelm S, Wittmann C, Blöcker H, Pühler A, Müller R: Complete genome sequence of the myxobacterium Sorangium cellulosum. Nat Biotechnol 2007, 25:|28|-|289.

27. Fieseler L, Hentschel U, Grozdanov L, Schirmer A, Wen GP, Platzer M, Hrvatin S, Butzke D, Zimmermann K, Piel J: Widespread occurrence and genomic context of unusually small polyketide synthase genes in microbial consortia associated with marine sponges. Appl Environ Microbiol 2007, 73:2। 44-2I 55.

28. Lorenz P, Eck J: Metagenomics and industrial applications. Nat Rev Microbiol 2005, 3:510-516.

29. Wenzel SC, Müller R: Recent developments towards the heterologous expression of complex bacterial natural product biosynthetic pathways. Curr Opin Biotechnol 2005, I 6:594-606.

30. Stackebrandt E, Pauker O, Steiner U, Schumann P, Straubler B, Heibei $S$, Lang E: Taxonomic characterization of members of the genus Corallococcus: Molecular divergence versus phenotypic coherency. Syst Appl Microbiol 2006, 30(2): I09-I I8.

31. Udwary DW, Zeigler L, Asolkar RN, Singan V, Lapidus A, Fenical W, Jensen PR, Moore BS: Genome sequencing reveals complex secondary metabolome in the marine actinomycete Salinispora tropica. Proceedings of National Academy of Sciences USA 2007, 104: I0376-1038I.

32. Beyer S, Kunze B, Silakowski B, Müller R: Metabolic diversity in myxobacteria: Identification of the myxalamid and the stigmatellin biosynthetic gene cluster of Stigmatella aurantiaca Sg a I 5 and a combined polyketide-(poly)peptide gene cluster from the epothilone producing strain Sorangium cellulosum So ce90. Biochim Biophys Acta 1999, 1445: 185-195.

33. Pfeifer BA, Khosla C: Biosynthesis of polyketides in heterologous hosts. Microbiol Mol Biol Rev 2001, 65:106-118.

34. Julien B, Shah S: Heterologous expression of epothilone biosynthetic genes in Myxococcus xanthus. Antimicrob Agents Chemother 2002, 46:2772-2778.

35. Perlova O, Fu J, Kuhlmann S, Krug D, Stewart F, Zhang Y, Müller R: Reconstitution of myxothiazol biosynthetic gene luster by Red/ET recombination and heterologous expression in Myxococcus xanthus. Appl Environ Microbiol 2006, 72:7485-7494.

36. Fu J, Wenzel SC, Perlova O, Gross F, Tang Z, Yin Y, Stewart AF, Müller R, Zhang Y: Efficient transfer of two large secondary metabolite pathways into heterologous hosts by transposition. Nucleic Acids Res 2008, 36:e I I3.

37. Wenzel SC, Gross F, Zhang Y, Fu J, Stewart FA, Müller R: Heterologous expression of a myxobacterial natural products assembly line in pseudomonads via Red/ET recombineering. Chem Biol 2005, I 2:349-356.

38. Nüske J, Fritsche W: Phaseolotoxin production by Pseudomonas syringae pv. phaseolicola - the influence of temperature. J Basic Microbiol 1989, 29:44 I-447.

39. Slininger PJ, Sheawilbur MA: Liquid culture $\mathbf{p H}$, temperature, and carbon (not nitrogen) source regulate phenazine productivity of the take-all biocontrol agent Pseudomonas fluorescens 2-79. Appl Microbiol Biotechnol 1995, 43:794-800.

40. Baneyx F: Recombinant protein expression in Escherichia coli. Curr Opin Biotechnol 1999, 10:41 I-421.

4I. Baneyx F, Mujacic M: Recombinant protein folding and misfolding in Escherichia coli. Nat Biotechnol 2004, 22: |399-|408.

42. Gross F, Ring MW, Perlova O, Fu J, Schneider S, Gerth K, Kuhlmann $S$, Stewart F, Zhang Y, Müller R: Red/ET-subcloning and heterologous expression of methylmalonyl-CoA biosynthesis genes of Sorangium cellulosum So ce56 in Pseudomonas putida KT2440. Chem Biol 2006, I 3: I253-I 264. 
43. Pradella S, Hans A, Sproer C, Reichenbach H, Gerth K, Beyer S: Characterisation, genome size and genetic manipulation of the myxobacterium Sorangium cellulosum So ce56. Arch Microbiol 2002, I 78:484-492.

44. Karlyshev AV, Pallen MJ, Wren BW: Single-primer PCR procedure for rapid identification of transposon insertion sites. Biotechniques 2000, 28:1078-1082.

Publish with Biomed Central and every scientist can read your work free of charge

"BioMed Central will be the most significant development for disseminating the results of biomedical research in our lifetime. " Sir Paul Nurse, Cancer Research UK

Your research papers will be:

- available free of charge to the entire biomedical community

- peer reviewed and published immediately upon acceptance

- cited in PubMed and archived on PubMed Central

- yours - you keep the copyright 